\title{
The Internationalization of Business and Their Approach to New Markets: A Focus on US Wine Consumer
}

\author{
Piero Mastroberardino ${ }^{1}$, Giuseppe Calabrese ${ }^{1}$, Flora Cortese $^{2} \&$ Miriam Petracca $^{2}$ \\ ${ }^{1}$ Department of Economics, University of Foggia, Foggia, Italy \\ ${ }^{2}$ Faculty of Law, Giustino Fortunato University, Benevento, Italy \\ Correspondence: Miriam Petracca, Faculty of Law, Giustino Fortunato University, Benevento, Italy. E-mail: \\ m.petracca@unifortunato.eu
}

Received: September 26, 2019

Accepted: October 28, 2019

Online Published: November 8, 2019

doi:10.5539/ijbm.v14n12p14

URL: https://doi.org/10.5539/ijbm.v14n12p14

\begin{abstract}
The paper develops an exploratory research. It aims to understand the elements considered by a wine company to enter the US market and the characteristics considered to be important for US wine consumers when choosing a wine. For this purpose, the paper conducts two different steps of study: (1) it analyzes the US wine market, through a secondary data set; and (2) it studies a random sample of 4,560 reviews of US wines consumers found on CellarTracker. After a reflection on cultural issues related to the internationalization of companies, the paper presents briefly the theme of cross-cultural management, which is fundamental for the approach to new markets, and then it focuses on the wine industry. The focus will be on the peculiarity of the production of Italian wine companies and their choices of internationalization, particularly in the US market. The analyses show that (1) the US market ranks first in terms of consumption and represents, among other things, the first destination area for Italian sales and (2) the US consumer is strongly focused on the organoleptic properties of the wine.
\end{abstract}

Keywords: wine business, internationalization, cross-cultural management, US wine market

\section{Introduction}

With globalization, the internationalization strategy appears no longer qualified as a discretionary option for companies that-with a certain financial and organizational potential-intend to grow outside national borders. On the contrary, it becomes increasingly necessary for the survival of those organizations that operate in saturated domestic markets and/or need to reduce production costs.

When firms start to look at internationalization, the theme of cultural differences appears strongly: should the product offer on single markets consider characteristics, tastes, and preferences of local consumers? Or just be a standardized product for everyone? Should the strategies adopted in foreign markets consider the cultural, demographic and market characteristics? In its relations, should the firm adopt a single approach, bringing its values and its rules in the world? Or should it create an advantageous climate by flattening the divergences in terms of values, managerial practices, and politically correct behaviors?

The analysis of the "host" country culture is therefore fundamental as it influences the approach to the market, the relationship with other actors in the competitive environment. Moreover, it affects the culture of the company itself, the organization and the management of processes.

Cross-cultural management can help companies to understand and manage value creation processes in countries other than their country of origin: (1) knowing the culture of the host country is a significant factor in reducing business risk and the uncertainty of approaches towards unknown markets, and (2) can also help to overcome internal and inter-organizational conflicts.

In the case of the wine business, the choice to internationalize a wine offer does not only mean selling abroad. Rather, it means to undertake with great care a process made of phases, activities, and operations of undoubted complexity, especially at the cultural level.

Focusing on the Italian wine sector, spearhead of the basket that makes up the agri-food "Made in Italy" in the world, the decision-making process is enriched with a further series of considerations related to the wine product, its cultural, hedonistic, and experiential background, to the evolution of the consumer, and the turbulent 
dynamics of international markets with specific reference to this sector.

This work presents briefly the theme of cross-cultural management, which is fundamental for the approach to new markets, and then it focuses on the wine industry. The focus is on the peculiarity of the production of Italian wine companies and their choices of internationalization, particularly in the US market. The work first presents an analysis, on secondary data, of the US wine market and then focuses on the study of the tastes of wine consumers in the United States, the most important export area for Italian wines.

\section{Cross-Cultural Management and the Approach to Different Markets}

The aforementioned competitive dynamics mean that companies today are increasingly multicultural: intra and inter-organizational relationships become more difficult, as well as communication becomes more complex. The international business environment is different from the domestic one because countries, societies, and cultures are different, and firms have to act in a more complicated way than in domestic markets.

Cross-cultural management (Hofstede, 1980a; Hofstede, 1908b; Hofstede, 2001; Trompenaars \& Hampden-Turner, 1997; Sagiv \& Schwartz, 2007; House, Hanges, Javidan, Dorfman, \& Gupta 2004) deals with the problems that arise between the members of the organization, and between the organization and other external actors. One of the main functions of cross-cultural management is, in fact, the effort to prevent the development of barriers within the organization, but also among it and other stakeholders (Greblikaite \& Daugeliene, 2010), for example improving institutional and commercial communication.

According to Adler and Gundersen (2008), cross-cultural management illustrates the conduct of people in firms placed in cultures and countries all over the world and explains to people how to work in organizations with workers and consumers with different cultures. Thus, cross-cultural management describes and compares organizational behavior within countries and cultures. On one hand, cross-cultural management observes and analyses the behavior of people with different cultural origins in organizations; on the other, it compares and studies cultural differences existing between firms belonging to different cultural backgrounds (Codignola, 2017).

Cross-cultural management researchers have mainly tried to analyze the relationship between culture, organizational behavior, and outcomes (Adler, 1983). For this reason-to deepen the effects of culture on commercial interaction in global markets-it is important to understand what culture is and means. Since the punctual reconstruction of literature on this subject is not the objective of this paragraph, it is fundamental to point out that culture is a concept that is difficult to define, even though it has long been studied by many business scholars. Since the ' 60 s management researchers have been paying attention to the concept of culture to demonstrate its effect on managerial behavior and market performance (Sekaran, 1983).

Among many, Hofstede (1980a, 1991) defined culture as the collective psychological program of individuals in a given environment. Culture is not an individual characteristic but involves a certain number of people who have been influenced by the same education and by the same life experiences. Hofstede has also carried out an innovative study on the culture that has given a great boost to the analysis of cultural differences in this field.

After him, House, Hanges, Javidan, Dorfman \& Gupta (2004) set up a model that allows measuring the cultural distance between countries, from which the Globe model descends.

The culture of the host country represents the main source of complexity in the decision-making process of firms in the internationalization phase: the cultural differences between countries and individuals make the approach to new markets and consumer behavior understanding more complex. Consumers have different needs, use contrasting selection criteria and are influenced by different social norms operating in their country (Arrigo \& Codignola, 2006).

\section{Internationalization in the Wine Sector and Its Peculiarities}

The cultural differences between countries and the different approaches to the markets of firms that decide to internationalize can be considered as two themes of particular importance for the wine business (among others, Calabrese \& Mastroberardino, 2016; Calabrese \& Mastroberardino, 2017a; Calabrese \& Mastroberardino, 2017b) and for Italian wine producers. The analysis of data on the evolutionary dynamics of the wine business places the wine industry among those characterized by a greater rate of internationalization. This is because, compared to a tendential reduction in internal consumption in terms of volumes and a structural excess of internal supply, the data on the growth of external markets are particularly attractive, often inducing the erroneous expectation of easy commercial penetration. On the other hand, the positioning of Italian wine, strongly linked to the concept of terroir, allows us to fully experience the importance of understanding cultural differences between countries and adopting the most appropriate strategic behavior. 
Before going into this type of reflection, it seems fundamental to present some data on world wine production and the role played by Italy in the international scenario, but also on wine consumption and international trade.

About production (Area Studi Mediobanca, 2019), in 2017 world wine production is assessed by the Organization International of Vine and Wine (OIV) at 251 million hectoliters, down in $2016(-8 \%)$. Italy was the first producer in 2017 with a share of $16.9 \%$ of the world total, followed by France (14.6\%). In 2017 the value of Italian production is 12.1 billion euros. A significant portion of Italian production is exported, with a positive balance passing from 760 million euros in 1990 to 5.7 billion in 2017 (over 7 times). The average export price increased from 2.70 euros to 2.77 euros per liter $(+2.6 \%)$.

Moving to the demand analysis (Organization International of Vine and Wine, 2019), world wine consumption in 2018 was estimated at 246 million hectoliters, slightly down compared to 2017. The United States of America, with an estimated consumption of 33 million hectoliters, confirms its position as the world's top consumer since 2011. Consumption in European countries, traditionally producers and consumers of wine, remains substantially stable, with France at 26.8 million hectoliters, Italy at 22.4 million hectoliters and Germany at 20 million hectoliters.

Finally, concerning the international trade (Organization International of Vine and Wine, 2019), in 2018 the world market, considered as the sum of exports of all countries, represents a volume of 108 million hectoliters, in slight growth (+ $0.4 \%$ ) compared to 2017, and a value of 31.3 billion euro, up 1.2\% compared to 2017 .

The analysis by country shows that the wine trade is largely dominated by Spain, Italy, and France, overall with $50.7 \%$ of the world market volume (54.8 million hectoliters). Concerning volumes, Spain confirms itself as the leading exporter, with 20.9 million hectoliters, equal to $19.4 \%$ of the world market; for the value of exports, France is the world's leading exporter in value, with 9.3 billion euros in 2018.

In 2018 the top five importing countries are Germany, the United Kingdom, the United States of America, France and China. Together they represent more than half of total imports.

About the areas of destination of Italian sales abroad (Area Studi Mediobanca, 2019), there is still a prevalence of proximity markets (EU countries) which absorbed $52.0 \%$ of foreign sales in 2018, in an increase on 2017 of $5.6 \%$ (when they weighed $51.7 \%$ ).

The United States of America is the leading destination market for Italian wines, followed by Germany. Exports remain concentrated in a few markets: the top four (the United States of America, Germany, the United Kingdom, and Switzerland) absorb $60 \%$ of total exports.

The evidence of a substantial market potential beyond domestic borders undoubtedly leads Italian wine companies to look to internationalization: the world of wine aims to expand into ever wider and heterogeneous geographical areas, which have different "cultures", both in general terms, both in food and wine terms.

Moving to some strategic considerations it is necessary to recall the clear contrast between firms belonging to the Old World, historical wine producers, and companies from Emerging Countries.

The producers of the Old World have always shown a strong product orientation, a predilection for some distinctive factors considered characteristic, peculiar and not replicable, represented by the link between wine, grape variety, territory, climate, a cultural and social component, which make wine a symbol of historical roots as well as geographical. They appeal to an evolved consumer, using a complex and sophisticated message.

This choice of positioning aims at marking the distance with the so-called Emerging Countries, which offer wines with a good quality/price ratio, for which the varietal profile of the product, especially the geographical logic, takes on value. As known, while terroir is not replicable in different contexts, some grape varietals (chardonnay, merlot, cabernet sauvignon, pinot noir, syrah, etc.) have shown particularly adaptable characters, allowing the global approach to the wine business and moving the competition on different terrain, closer to price competition. In these countries, wine is closer to a commodity model, and the target audience is the average consumer. In terms of communication, while using territorial elements, investments in marketing are huge and the message is more accessible and immediate.

Focusing on the positioning of Italian wine, it should be emphasized that the Italian wine offer finds its most important strengths in the winemaking tradition, in the strong territorial characterization of its wines and the wide variety of native vines. All elements are easily traceable to the Made in Italy value system, based on the excellence of Italian products.

\section{Cross-Cultural Studies in the Wine Sector}

Cultural differences can represent an obstacle to internationalization if not managed as a driver for the success of 
a business. In the "Food \& Beverage" sector this is even more true as consumers living in different countries, even if they are close both geographically and culturally-for example those living in the European Union - present deeply different preferences and food choices (Askegaard \& Madsen, 1995). This is because eating habits are formed since birth, under the influence of social groups (family, friends, school, etc.) that interact with the individual. They also represent identity choices and, therefore, are an expression of cultural differences (Cohen et al., 2009).

Wine is certainly a product whose consumption is linked to and influenced by the local culture. Let's just consider that it is an asset of the Christianity culture and is a source of poetic and musical inspiration, as well as the object of much literature and iconography since ancient times (Cohen et al., 2009).

Therefore, consumers from geographically and socially diverse areas have specific preferences and expectations for wine products. Consider, for example, the cultural differences between Eastern and Western countries: about wine, the Asian market is different from the European market in terms of relative preferences and cultural values (Yoo et al., 2013). It has been shown (Somogyi et al., 2007), that Chinese consumers prefer sweet wine, but tend to drink more red wine because of potential health benefits. On the contrary, it is unlikely that European consumers will tend to consider wine as a healthy product. Therefore, the food preferences are influenced by the culture in which the individual socializes while the preference for a food product can vary according to the context of the consumer (Yoo et al., 2013).

In literature, the subject is much debated and several contributions have analyzed the cross-cultural differences in the wine sector. According to Rodrigues \& Parr (2019) researches on the topic can be classified into 5 macro-categories:

1. Intrinsic qualities of wine, i.e. those related to the wine itself-organoleptic properties (color, clarity, fluidity, acidity, flavor, astringency, tannins, and so on)—or those experienced by tasting it— the tasters' responses to the organoleptic properties of culture (Shankar et al., 2010; Torri et al., 2012; Williamson et al., 2012; Mouret et al., 2013; Saenz-Navajas et al., 2013; Parr et al., 2015; Valentin et al., 2016);

2. Extrinsic qualities of the wine, i.e. the quality elements relating to wine that are not physically part of it, such as the brand, the price, the label, the awards, the origin of wine, and the technical methods of production (Yoo et al., 2013; Saenz-Navajas et al., 2014; Wan, Zhou, et al., 2015; Wan, Woods, et al., 2015);

3. Conceptual studies, including those on the cerebral representation of wine, used to collect data on how an individual, alone or in a group, conceptualizes an aspect of his life, such as, for example, what they think of wine (Parr et al., 2011; Mouret et al., 2013);

4. Consumer attitudes, beliefs and/or opinions; i.e. those studies that used different methods to investigate a range of topics related to the conceptualisation of wine according to culture (Do et al., 2009; Stolz and Schmid, 2008; de Magistris et al., 2011; Charters et al., 2011; Chang, Thach and Olsen, 2016; Vecchio et al., 2017);

5. Research investigating the emotional response to wine, i.e. those investigating the emotional response of consumers to the intrinsic and extrinsic aspects of wine (Parr, 2003; Ferdenzi et al., 2013).

\section{Research Objective, Material, and Methods}

This paper develops an exploratory research and aims at answering the following questions:

- Why an Italian wine company should decide to enter the US market? In other words, what are the elements that a wine company that decides to enter the US market must take into account to be successful?

- What are the characteristics that US wine consumers consider important when choosing a wine?

To answer the research questions, the paper conducts two different steps of study:

1. It analyzes the US wine market, through a secondary data set;

2. It studies the reviews of US wines consumers, in this case, most of all collectors of wine, found on Cellar Tracker, which is one of the most complete wine databases in the world.

The first step aims at understanding the peculiarities of the US wine market to bring out the key elements that a wine company must take into consideration when it decides to enter it. To this end, data on the US wine market of the WineMonitor and Nomisma report (2017) are presented and analyzed.

The second has the purpose of understanding the fundamental elements that US consumers consider when they 
choose a wine. To this purpose, a random sample of 4,560 reviews was extracted through Scrapy-an open-source and collaborative framework for extracting data from websites (Scrapy, 2019) - from Cellar Tracker-a community of millions of people, who share information about wines-were analyzed. Cellar Tracker was created in March 2003 by Eric LeVine as a way to keep track of his winery. Having extended the site to allow two friends to use it, Eric was intrigued by the potential to create a wider phenomenon. In July 2003 it launched a small beta program for Cellar Tracker that grew up to 100 users who tracked 60,000 wines. Now Cellar Tracker is the winery's main management tool with hundreds of thousands of collectors tracing over 75 million wines. Cellar Tracker has also grown to become the largest database of community tasting notes with over 5.8 million notes by the end of 2016. With tasting notes, market values and inventory management for each wine, the Cellar Tracker database is an invaluable resource for occasional professionals and oenophiles. Every year many millions of wine lovers come to the site to read reviews and collect wine recommendations (Cellar Tracker, 2019). The decision to analyze such reviews was based on the fact that word of mouth (WOM) is a form of communication that contributes to the spread of consumers' perceptions - it is a communication tool that allows news to be transmitted and the opinions and attitudes of consumers to be influenced through the spontaneous exchange of information. With the birth and consequent expansion of information and communication technologies, 'electronic word of mouth' caught on. This is generally defined as e-WOM and is closely linked to user-generated content. In the wine sector, as in other fields-for example, the tourism sector (Cortese, D'Ambrosio, Petracca, 2019; Petracca, 2019) - the analysis of electronic and online WOM can facilitate the understanding of consumers' perceptions, in this case, users, regarding some aspect of the sector. With the birth of the first wine consumption blogs, attention has been focused on the role played by consumer experience in suggesting wine recommendations, making the purchase fun, simple, accessible and effortless for the wine consumer. The decision to consider Cellar Tracker, a community that could be defined as "expert", derives from the positioning of Italian wine.

It should be emphasized that, in addition to the quantitative aspects that outline the production and consumption trends, the US market has also been affected in recent years by changes attributable to the evolution of the consumer: in recent decades there has been expansion of the wine lovers segment, a category of buyers who are careful to acquire more and more awareness of the product, its technical and qualitative characteristics, concerned with acquiring a wealth of experience and information suitable to make it an actress as independent as possible in the dynamics characterizing the purchasing process.

The analysis is conducted as follows:

1. WineMonitor \& Nomisma data processing;

2. Analysis of the most frequently used words in the review sample and the creation of analysis categories.

\section{Results}

This section shows the results of the two steps of analysis: the first presents the results of the US wine market overview; the second is about the outcome of the Cellar Tracker's reviews.

\subsection{US Wine Market Overview}

The United States of America is an extremely interesting country for the wine sector: it is in first place for consumption and represents, among other things, the first destination area for Italian sales.

Before analyzing in detail the US wine market and its preferences (WineMonitor \& Nomisma, 2017) it is necessary to start by saying that, in the context of alcoholic beverages, beer in the United States of America is largely preferred to wine. In 2016, out of a total of 303 million hectoliters, $80 \%$ of the volume of alcoholic beverages consumed involved beer, $10 \%$ wine, $6 \%$ spirits and the remaining $4 \%$ ready-to-drink. In 2016, per capita consumption stood at 9.8 liters per year. However, consumption is not homogeneous in the various areas of the country: in $2015,44 \%$ of wine consumption was concentrated in five States, California (16.2\%), Florida (8.4\%), New York (7.9\%), Texas (6.9\%) and Illinois (4.4\%). Considering the age groups of consumers, the "millennials" (those born after 1980) represent in 2015 the segment of the population to which $42 \%$ of wine consumption in the US is attributable; followed by the "baby boomers" with $30 \%$.

Even if the US is among the largest producers in terms of volumes, they are confirmed for 2018 as the largest importer of wines in terms of value, while they are confirmed in third place, behind Germany and the United Kingdom, for what concerns volumes (OIV, 2019). Among the supplying countries, Italy is a leader. In 2016, the Italian market share is equal to $32 \%$ in value and $29 \%$ in volume.

From a survey conducted by Wine Monitor and Nomisma (2017), the wine selection criteria see the brand reputation of the winery in first place with $18 \%$ of preferences, the low price/promotion in second place with $16 \%$ 
of preferences, followed by the advice and recommendations (friends/shopkeepers) with 13\% and packaging/label and organic brand both with $10 \%$.

The most used channel for purchases is the wine/liquor store channel with a percentage of $37 \%$, followed by a mass retailer/warehouse with $25 \%$ and supermarket/grocery store with $20 \%$.

A certain complexity of the US market certainly emerges by reading these data, certainly due to the number of countries involved and the cultural differences between them. There is no particular "culture" of wine: the consumer is not an expert, he lets himself be guided by the brand or by the advice of friends/shopkeepers, or by low prices, and often buys in the promotion. Opportunities for use are mainly outside the home, in restaurants or cellars.

\subsection{Cellar Tracker Reviews Analysis}

Preliminary results on the random sample of the 4,560 reviews were obtained. Table 1 shows the frequencies of the first 100 words used by users in reviewing wines on Cellar Tracker.

Table 1 . The first 100 words by frequency

\begin{tabular}{|c|c|c|c|c|c|c|c|}
\hline Word & Freq. & Word & Freq. & Word & Freq. & Word & Freq. \\
\hline wine & 2793 & tasted & 429 & vanilla & 273 & white & 207 \\
\hline nose & 2067 & hours & 402 & drinking & 264 & dinner & 204 \\
\hline fruit & 2019 & opened & 390 & rich & 264 & taste & 204 \\
\hline palate & 1563 & light & 369 & hour & 261 & green & 201 \\
\hline finish & 1335 & better & 366 & showed & 261 & smooth & 201 \\
\hline nice & 1170 & balanced & 357 & structure & 258 & beautiful & 195 \\
\hline bottle & 933 & big & 357 & floral & 249 & down & 195 \\
\hline notes & 828 & tasting & 354 & pretty & 246 & integrated & 195 \\
\hline tannins & 669 & spice & 348 & leather & 243 & lemon & 195 \\
\hline dark & 642 & balance & 342 & note & 237 & night & 189 \\
\hline red & 639 & complex & 339 & chocolate & 234 & bottles & 186 \\
\hline years & 630 & showing & 327 & hint & 231 & nicely & 186 \\
\hline like & 615 & deep & 321 & plenty & 231 & minerality & 183 \\
\hline great & 606 & drink & 321 & think & 231 & spicy & 183 \\
\hline time & 582 & open & 321 & wines & 231 & blackberry & 180 \\
\hline oak & 576 & last & 315 & earth & 228 & bright & 177 \\
\hline cherry & 543 & shows & 309 & acid & 225 & coffee & 174 \\
\hline medium & 525 & ripe & 306 & complexity & 225 & delicious & 174 \\
\hline sweet & 522 & mouth & 294 & tobacco & 225 & pepper & 174 \\
\hline acidity & 504 & fruits & 285 & glass & 222 & strong & 171 \\
\hline long & 492 & young & 285 & best & 213 & depth & 165 \\
\hline color & 447 & wow & 279 & touch & 213 & interesting & 165 \\
\hline black & 444 & right & 276 & aromas & 210 & mouthfeel & 165 \\
\hline first & 435 & lovely & 273 & smoke & 210 & tight & 165 \\
\hline flavors & 429 & tannic & 273 & age & 207 & body & 162 \\
\hline
\end{tabular}

The most frequent word is 'wine', repeated 2793 times, followed by 'nose', repeated 2067 times, and 'fruit', repeated 2019 times. The Table 1 shows that, among the most frequently used words to describe a wine, many refer to organoleptic properties (i.e. 'dark', 'acidity', 'flavors', 'fruits', 'tobacco', 'lemon', 'coffee', and so on).

For this reason, a second analysis step has been conducted. It aims to understand which are the most considered features by US wine consumers, in this case, represented by Cellar Tracker users, when they choose a wine and describe it. This analysis consisted of grouping the first 100 words presented in Table 1 into more general categories of attributes (Table 2). 
Table 2. General categories of attributes

\begin{tabular}{|c|c|c|c|c|c|}
\hline \multicolumn{2}{|c|}{ Smell and taste characteristics } & \multicolumn{2}{|c|}{ Aromatic and flavor characteristics } & \multicolumn{2}{|c|}{ Wine extrinsic characteristics } \\
\hline fruit/fruits & 2304 & notes & 828 & bottle/bottles & 1119 \\
\hline tannins & 669 & flavors & 429 & years & 630 \\
\hline oak & 576 & tasted & 429 & young & 285 \\
\hline cherry & 543 & balanced & 357 & glass & 222 \\
\hline spice & 348 & tasting & 354 & age & 207 \\
\hline vanilla & 273 & note & 237 & body & 162 \\
\hline floral & 249 & hint & 231 & \multicolumn{2}{|c|}{ Wine intrinsic characteristics } \\
\hline leather & 243 & touch & 213 & sweet & 522 \\
\hline chocolate & 234 & aromas & 210 & acidity & 504 \\
\hline tobacco & 225 & taste & 204 & complex & 339 \\
\hline lemon & 195 & \multicolumn{2}{|c|}{ Visual characteristics } & ripe & 306 \\
\hline blackberry & 180 & dark & 642 & lovely & 273 \\
\hline coffee & 174 & red & 639 & tannic & 273 \\
\hline pepper & 174 & color & 447 & structure & 258 \\
\hline \multicolumn{2}{|c|}{ Sense characteristics } & black & 444 & acid & 225 \\
\hline nose & 2067 & light & 369 & complexity & 225 \\
\hline palate & 1563 & deep & 321 & green & 201 \\
\hline finish & 1335 & white & 207 & smooth & 201 \\
\hline mouth & 294 & bright & 177 & minerality & 183 \\
\hline mouthfeel & 165 & depth & 165 & spicy & 183 \\
\hline
\end{tabular}

Six categories of attributes have been identified (Table 2): (1) 'Smell and taste characteristics', containing 14 words related to odors and flavors, such as 'fruit', 'tannins', and 'chocolate; (2) 'Sense characteristics', containing 5 words somehow related to the five human senses; (3) 'Aromatic and flavor characteristics', containing 10 words related to the aroma and the flavor; (4) 'Visual characteristics', containing 9 words referred to visual elements of wine; (5) 'Wine extrinsic characteristics', containing 6 words which refer to external elements of wine; and (6) 'Wine intrinsic characteristics', containing 13 words referring to internal elements of wine. They represent the $57 \%$ (57 out of 100) of the first 100 words used by Cellar Tracker users (Table 1) to describe a wine.

\section{Discussion and Conclusions}

The knowledge of the cultures of the countries in which a firm intends to operate, of language and commercial practices, is the basis of every internationalization strategy. The analysis of the cultural distance between countries (the degree of difference and similarity between cultural values) becomes fundamental in order to operate at its best: the entrepreneurs are called to read the context in which they are going to work, to evaluate the margins of action, to understand the problem areas in which a relationship with the various stakeholders will take place.

The research described in this paper analyzed the cultural aspect that influences the choice of a particular wine and, consequently, the success of an internationalization business strategy. The paper focused first on the US wine market and then on the US consumers, although at a good level of skill and experience, given that Cellar Tracker - the used review site — is used mostly by wine collectors.

The results of this analysis can be summarized as follows. First of all, it tried to answer the first research question "Why a wine firm should decide to enter the US market? Or, what are the elements that a wine firm that decides to enter the US market must take into account to be successful?". The first step of analysis shows that although the alcoholic beverage preferred by US consumers is beer, which represents $80 \%$ of the alcohol market (wine stands at 10\%), the US market ranks first in terms of consumption and represents, among other things, the first destination area for Italian sales. Moreover, despite is one of the largest producers in terms of volumes, it is the largest importer of wines in terms of value and third in terms of volumes.

Regarding the second research question, which is "What are the characteristics that US wine consumers consider important when choosing a wine?" the analysis gives a frame of a US consumer strongly focused on the organoleptic properties of the wine. As a matter of fact, among the first 100 words most used by US consumers to describe wine (Table 1), 57 words $(57 \%)$ refer to the organoleptic properties and fall into one of the 6 
identified categories (Table 2). More in detail, most of the words used to describe a wine refer to "Smell and taste characteristics" (i.e. fruit, spice, floral, tobacco, chocolate, leather, coffee, pepper), "Wine intrinsic characteristics" (sweet, acidity, smooth, mineral, tannic, spicy), "Aromatic and flavors characteristics" (notes, flavor, touch, hint, aromas), "Visual characteristics" (dark, red, color, black, white), to the "Wine extrinsic characteristics" (bottle, year, age) and finally "Sense characteristics" (nose, palate, mouth).

These results show that it is important to also go deeper into the knowledge of consumer preferences. In fact, if an Italian wine company stopped to the fact that US consumers have different preferences (i.e. beer or spirits), it would never enter the US market. The results, however, show that the US market is the first destination area for Italian wines. This means that Italian wines are highly appreciated by US consumers and that they consider the geographical origin as a determining factor in the purchase choice. In addition, knowing the preferences of wine consumers, in terms of characteristics to be possessed, is important for a company aiming at pursuing an internationalization strategy. An Italian wine company must take into account that US consumers pay a lot of attention to the organoleptic characteristics of wine if it wants the internationalization strategy to be successful.

Passing to the paper's limitations, this work provides the results of the first step of an exploratory analysis and is limited to a small random sample of Cellar Tracker's reviews. Moreover, Cellar Tracker is a winery's management tool of principally collectors of wines. Therefore, it only reflects the opinions of a type of wine consumer: (1) those who are confident with technology and are inclined to leave their comments on the Web; (2) those who are wine collectors, attentive above all to certain characteristics of wine (drinkability, vintage, producer, overall state of preservation of the wine, color of the wine, organoleptic characteristics).

\section{Acknowledgements}

The article is the result of the joint work of the authors. In the editing phase, Piero Mastroberardino oversaw sections 1 and 7, Giuseppe Calabrese sections 4 and 5, Flora Cortese sections 3, 6, and 6.1 and Miriam Petracca sections 2 and 6.2.

\section{References}

Adler, N. J. (1983). Cross-cultural management research: The ostrich and the trend. Academy of Management Review, 8(2), 226-232. https://doi.org/10.5465/amr.1983.4284725

Adler, N. J., \& Gundersen, A. (2008). International dimensions of organizational behavior. OH: South-Western Cengage Learning, Mason. https://doi.org/10.1002/tie.5060280112

Area Studi Mediobanca. (2019). Indagine sul settore vinicolo. Retrieved from https://www.mbres.it/sites/default/files/resources/download_it/Indagine_vini_2019.pdf

Arrigo, E., \& Codignola, F. (2006). Imprese globali e cross-cultural management. Progetto di Ricerca di Rilevante Interesse Nazionale, 71-90.

Askegaard, S., \& Madsen, T. K. (1995). European food cultures: An exploratory analysis of food related preferences and behaviour in European regions. MAPP. Retrieved from http://pure.au.dk/portal/files/34302276/wp26.pdf

Brondoni, S. (2017). Managerial Economics and Global Corporations. Torino: Giappichelli Editore. https://doi.org/10.4468/2005.1.02brondoni

Calabrese, G., \& Mastroberardino, P. (2016). Internationalization of Family Business in High-Range Italian Wine. The Perspective of Some Italian Key Players. International Marketing Trend Conference, Conference Proceedings. http://archives.marketing-trends-congress.com/2016/pages/PDF/CALABRESE_MASTROBERARDINO.p df

Calabrese, G., \& Mastroberardino, P. (2017a). The concept of wine in the perception of supply and demand. An exploratory analysis at international level. International Marketing Trend Conference, Conference Proceedings. Retrieved from http://archives.marketing-trends-congress.com/2017/pages/PDF/160.pdf

Calabrese, G., \& Mastroberardino, P. (2017b). Strategie di customer engagement. La sfida del coinvolgimento dei millennials nel wine business. Conference Proceeding Convegno Sinergie - Sima 2017 dal titolo Value co-creation: le sfide di management per le imprese e per la società. Retrieved from https://www.sijm.it/wp-content/uploads/2018/11/full-paper-conference-proceedings-2017-parte-I-1.pdf

Cellar, T. (2019). About us. Retrieved from https://www.cellartracker.com/about.asp

Chang, K. J., Thasch, M. L., \& Olsen, J. (2016). Wine and health perceptions: Exploring the impact of gender, 
age and ethnicity on consumer perceptions of wine and health.Wine Economics and Policy, 5(2), 105-113. https://doi.org/10.1016/j.wep.2016.09.001

Charters, S., Velikova, N., Ritchie, C., Fountain, J., Thach, L., Dodd, T. H., Fish, N., Herbst, F., \& Terblanche, N. (2011). Generation Y and sparkling wines: a cross-cultural perspective. International Journal of Wine Business Research, 23(2), 161-175. https://doi.org/10.1108/17511061111143016

Codignola, F. (2017). Global Corporate Culture and Cross-Cultural Management. In S. Brondoni (Ed.), Managerial Economics and Global Corporations. Torino: Giappichelli Editore. https://doi.org/10.4468/2005.1.02brondoni

Cohen, E., Goodman, S., d'Hauteville, F., \& Sirieix, L. (2009). A cross-cultural comparison of choice criteria for wine in restaurants. International Journal of Wine Business Research. https://doi.org/10.1108/17511060910948035

Cortese, F., D'Ambrosio, I., \& Petracca, M. (2019). A Possible Synergy between Culture and Religion for the Sustainability of Tourism of Pompeii. Sustainability, 11(8), 2231. https://doi.org/10.3390/su11082231

Do, V. B., Patris, B., \& Valentin, D. (2009). Opinions on wine in a new consumer country: A comparative study of Vietnam and France. Journal of Wine Research, 20(3), 253-271. https://doi.org/10.1080/09571260903471894

de Magistris, T., Groot, E., Gracia, A., \& Miguel Albisu, L. (2011). Do millennial generation's wine preferences of the "New World" differ from the "Old World"? A pilot study. International Journal of Wine Business Research, 23(2), 145-160. https://doi.org/10.1108/17511061111143007

Ferdenzi, C., Roberts, S.C., Schirmer, A., Delplanque, S., Cekic, S., Porcherot, C., Cayeux, I., Sander, D., \& Grandjean, D. (2013). Variability of affective responses to odors: Culture, gender, and olfactory knowledge. Chemical senses, 38(2), 175-186. https://doi.org/10.1093/chemse/bjs083

Greblikaite, J., \& Daugeliene, R. (2010). The growing need of cross-cultural management and ethics in business. European Integration Studies, 4, 148-152.

Hofstede, G. (1980a). Culture's Consequences: International Differences in Work-Related Values. Los Angeles: SAGE.

Hofstede, G. (1980b). Motivation, leadership, and organization: do American theories apply abroad? Organizational Dynamics, 9(1), 42-63. https://doi.org/10.1016/0090-2616(80)90013-3

Hofstede, G. (1991). Cultures and Organizations: Software of the Mind. London: McGraw-Hill.

House, R. J., Hanges, P. J., Javidan, M., Dorfman, P. W., \& Gupta, V. (2004), Culture, leadership, and organizations: The GLOBE study of 62 societies. Sage publications.

Mouret, M., Monaco, G. L., Urdapilleta, I., \& Parr, W. V. (2013). Social representations of wine and culture: A comparison between France and New Zealand. Food Quality and Preference, 30(2), 102-107. https://doi.org/10.1016/j.foodqual.2013.04.014

Organization International of Vine and Wine. (2019). Nota di congiuntura mondiale. Situazione del settore nel 2018. April 2019. Retrieved from http://www.oiv.int/public/medias/6681/it-oiv-nota-di-congiuntura-mondiale-2019.pdf

Parr, W.V. (2003). The ambiguous nature of our sense of smell. The Australian \& New Zealand Grapegrower \& Winemaker: 31st Annual Technical Issue. 473a, 114-211.

Parr, W. V., Ballester, J., Peyron, D., Grose, C., \& Valentin, D. (2015). Perceived minerality in Sauvignon wines: Influence of culture and perception mode. Food Quality and Preference, 41, 121-132. https://doi.org/10.1016/j.foodqual.2014.12.001

Parr, W. V., Mouret, M., Blackmore, S., Pelquest-Hunt, T., \& Urdapilleta, I. (2011). Representation of complexity in wine: Influence of expertise. Food Quality and Preference, 22(7), 647-660. https://doi.org/10.1016/j.foodqual.2011.04.005

Petracca, M. (2019). L'immagine turistica nell'era del travel 2.0. Il ruolo degli user-generated content e dell'electronic word-of-mouth. Milano: FrancoAngeli.

Rodrigues, H., \& Parr, W. V. (2019). Contribution of cross-cultural studies to understanding wine appreciation: A review. Food Research International, 111, 251-258. https://doi.org/10.1016/j.foodres.2018.09.008

Sagiv, L., \& Schwartz, S.H. (2007). Cultural values in organisations: Insights for Europe. European Journal of 
International Management, 1(3), 176-190. https://doi.org/10.1504/EJIM.2007.014692

Sáenz-Navajas, M. P., Ballester, J., Pêcher, C., Peyron, D., \& Valentin, D. (2013). Sensory drivers of intrinsic quality of red wines: Effect of culture and level of expertise. Food research international, 54(2), 1506-1518. https://doi.org/10.1016/j.foodres.2013.09.048

Sáenz-Navajas, M. P., Ballester, J., Peyron, D., \& Valentin, D. (2014). Extrinsic attributes responsible for red wine quality perception: A cross-cultural study between France and Spain. Food Quality and Preference, 35, 70-85. https://doi.org/10.1016/j.foodqual.2014.02.005

Scrapy. (2019). Available online:https://scrapy.org/, (accessed on $1^{\text {st }}$ May 2019).

Sekaran, U. (1983). Methodological and theoretical issues and advancements in cross-cultural research. Journal of international business studies, 14(2), 61-73. https://doi.org/10.1057/palgrave.jibs.8490519

Shankar, M. U., Levitan, C. A., \& Spence, C. (2010). Grape expectations: The role of cognitive influences in

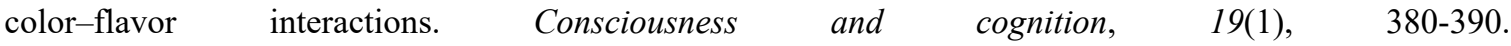
https://doi.org/10.1016/j.concog.2009.08.008

Somogyi, S., Li, E., Johnson, T., Bruwer, J., \& Bastian, S. (2007). An examination of the attitudes and behaviours of ethnic Chinese wine consumers: an exploratory study. In Proceedings of the 2007 Australian and New Zealand Marketing Academy Conference (ANZMAC 2007) (pp. 2032-2040). University of Otago, School of Business. $\quad$ Retrieved from https://eprints.usq.edu.au/6950/3/Somogyi_Li_Johnson_Bruwer_Bastian_2007_PV.pdf

Stolz, H., \& Schmid, O. (2008). Consumer attitudes and expectations of organic wine. Organic wine and viticulture conference. Levizzano, Italy, 2008. Retrieved from http://orgprints.org/13974/1/stolz-schmid-2008-IFOAM_WineCongress_Consumer_study-final_paper.pdf

Torri, L., Noble, A. C., \& Heymann, H. (2013). Exploring American and Italian consumer preferences for Californian and Italian red wines. Journal of the Science of Food and Agriculture, 93(8), 1852-1857. https://doi.org/10.1002/jsfa.5979

Trompenaars, F., \& Hampden-Turner, C. (1997). Riding the Waves of Culture: Understanding cultural diversity in business. London: Mc-Graw Hill.

Valentin, D., Parr, W. V., Peyron, D., Grose, C., \& Ballester, J. (2016). Colour as a driver of Pinot noir wine quality judgments: An investigation involving French and New Zealand wine professionals. Food Quality and Preference, 48, 251-261. https://doi.org/10.1016/j.foodqual.2015.10.003

Vecchio, R., Decordi, G., Grésillon, L., Gugenberger, C., Mahéo, M., \& Jourjon, F. (2017). European consumers' perception of moderate wine consumption on health. Wine Economics and Policy, 6(1), 14-22. https://doi.org/10.1016/j.wep.2017.04.001

Wan, X., Woods, A. T., Butcher, N., \& Spence, C. (2015). When the shape of the glass influences the flavour associated with a coloured beverage: evidence from consumers in three countries. Food Quality and Preference, 39, 109-116. https://doi.org/10.1016/j.foodqual.2014.07.004

Wan, X., Zhou, X., Woods, A. T., \& Spence, C. (2015). Influence of the glassware on the perception of alcoholic drinks. Food Quality and Preference, 44, 101-110. https://doi.org/10.1016/j.foodqual.2015.03.018

Williamson, P. O., Robichaud, J., \& Francis, I. L. (2012). Comparison of Chinese and Australian consumers' liking responses for red wines. Australian Journal of Grape and Wine Research, 18(3), 256-267. https://doi.org/10.1111/j.1755-0238.2012.00201.x

Wine Monitor, \& Nomisma. (2017). I "fine wines" nel mercato US. October 2017.

Wine Monitor, \& Nomisma. (2019). Scenari evolutivi di mercato e prospettive per i vini campani. 29 march 2019

Yoo, Y. J., Saliba, A. J., MacDonald, J. B., Prenzler, P. D., \& Ryan, D. (2013). A cross-cultural study of wine consumers with respect to health benefits of wine. Food Quality and Preference, 28(2), 531-538. https://doi.org/10.1016/j.foodqual.2013.01.001 


\section{Copyrights}

Copyright for this article is retained by the author(s), with first publication rights granted to the journal.

This is an open-access article distributed under the terms and conditions of the Creative Commons Attribution license (http://creativecommons.org/licenses/by/4.0/). 